\title{
SAKURAJIMA: MAINTAINING AN ISLAND ESSENCE
}

[Received October 16th 2014; accepted December 12th 2014 - DOI: 10.21463/shima.10.1.07]

\author{
Henry Johnson \\ University of Otago <henry.johnson@otago.ac.nz> \\ Sueo Kuwahara \\ Kagoshima University <kuwahara@Ieh.kagoshima-u.ac.jp>
}

\begin{abstract}
Sakurajima (Cherry Island) began its existence about 26,0oo years ago as a volcanic island rising from the northern end of Kagoshima Bay in the south of the island of Kyūshū, Japan. What makes Sakurajima a topic of significance in the field of Island Studies is that it is no longer an island, yet maintains many island-like characteristics-an island essence. In 1914, there was a major volcanic eruption on Sakurajima with a massive lava flow that covered several parts of the island and beyond, and joined it to the Ôsumi Peninsula as part of Kyūshū. Sakurajima is a part of Kagoshima City, the capital city of Kagoshima Prefecture, but the main urban part of the city is located about $3.8 \mathrm{~km}$ across the water from Sakurajma on the Satsuma Peninsula. This paper examines the life of Sakurajima from island to peninsula, and argues that the former island maintains an island-like identity through such factors as toponymy, shape, travel and tourism. Even though Sakurajima is now a peninsula, which is joined to another peninsula on a much larger island, it is discussed in terms of its islandness as determined by its features, attractions and predominant mode of transport to and from the former island.
\end{abstract}

KEYWORDS: Islandness, Japan, Kagoshima, peninsula, Sakurajima, toponymy, volcano.

\section{Introduction}

In the summer and autumn of 2012, JR Kyūshū (Japan Railways Kyūshū) ran a campaign promoting the islands of Kagoshima. In addition to Kagoshima (Fawn Island) itself, which refers to both the prefecture and its capital city, five islands were identified: Chiringashima (Chirin Island), Koshikijima (Steaming Pot Island), Nagashima (Long Island), Kirishima (Fog Island) and Sakurajima (Cherry Island). The promotion emphasized these islands in terms of 'sea', 'road' and 'mountain' routes (umi no shima, michi no shima and yama no shima, respectively). 3 But what sets these islands apart is that not all of them are surrounded by water, and each has distinct characteristics that either extends or challenges the notion of 'island'. Chiringashima is surrounded by water, but only at high tide; Koshikijima is a term for an archipelago, Koshikijima-rettō, which comprises KamiKoshikijima (Upper Koshiki Island), Naka-Koshikijima (Middle Koshiki Island) and ShimoKoshikijima (Lower Koshiki Island) (the first two islands have a connecting bridge); Nagashima is an island connected to the mainland by a bridge; Kirishima is a mountain (it is also the name of a city); and Sakurajima is a former island that was joined to the mainland as the result of a lava flow. The JR marketing campaign shows that Kagoshima might be appealing to tourists because of these three types of shima: Nagashima, 
Koshikijima and Chiringashima are islands surrounded by sea; Sakurajima is a former island and a part of Kagoshima City; and Kirishima is the name of a mountain range that includes several peaks (Karakunidake, Shinmoedake, Nakadake, and Takachiho no Mine), which look like islands rising from the land. Thus, when referring to Kagoshima as a tourist destination, the notion of islandness is embodied within such marketing. These shima (islands) offer some slightly different interpretations of the notion of 'island' in the Japanese context, each of which allows for a broader definition of the term. In particular, Sakurajima stands out as a former island, a place that maintains a short ferry service and has a road bridge (they are on opposite sides of the 'island'), and a landmass that maintains a distinct sense of of islandness. It is this location that isthe focus of this paper, one that offers a site where the notion of 'island' is manifest as a result of social, cultural and environmental influences and sensibilities.

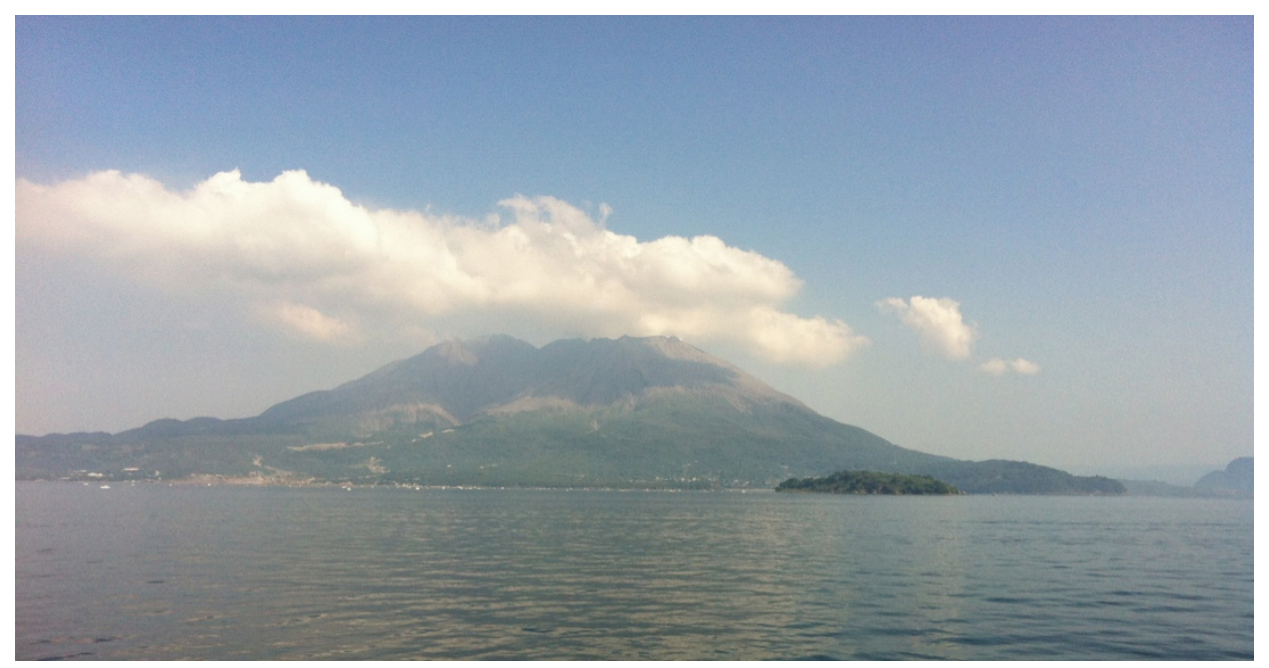

Figure 1 - Sakurajima (with Okogashima in the foreground). (Photo: Henry Johnson, 2012.)

The name 'Sakurajima' (Cherry Island) conjures up an image of an island covered with cherry trees and a focal point for the Japanese Cherry Blossom Festival (Sakura Matsuri), as one of the nation's biggest celebrations. Flocks of people gather to view the eye-catching pink blossoms and to enjoy this highly celebrated spring spectacle. For Sakurajima, which has a population of around 4700 residents, while the Cherry Blossom Festival is just as much a part of seasonal, visual and floral celebration for this part of Japan as it is elsewhere in the Japanese archipelago, such festivities, along with many other aspects of everyday life in this location to the south of the island of Kyūshū, are dominated by a much more formidable part of the physical environment. Sakurajima is characterised not by cherry trees, but by a $1117 \mathrm{~m}$ high volcano that currently spews ash on an almost daily basis over much of the surrounding area. Known for several extremely violent explosions over the centuries, with the most recent in $1914,{ }^{5}$ those who live on Sakurajima are constantly reminded of the volcano's threat to life, and even residents living in the main urban part of Kagoshima City 3.8 km across Kagoshima Bay (Kinko-wan; also called Kagoshima-wan)

\footnotetext{
${ }^{1}$ The term hanami (flower viewing) is used to refer to the aesthetic practice of viewing cherry blossoms.
} 
often experience ash fall and the disruption this can bring to daily life. Indeed, the 1914 eruption was such that its lava flow actually joined the Sakurajima to the mainland by filling the roughly $70 \mathrm{~m}$ deep and $400 \mathrm{~m}$ wide sea passage, and thus transforming its island identity. As a result of the eruption and earthquakes that accompanied it, " 58 [people] were killed or missing, 112 were injured, 2,148 houses were burned down and 315 houses were partially or wholly destroyed" (Sakurajima Taishō Funka 100-shūnen Jigyō Jikkō Iinkai, 2014). With this eruption, about 60 percent of the then 3400 houses on Sakurajima were destroyed, and six villages were buried with lava (Sakurajima Taishō Funka 10o-shūnen Jigyō Jikkō linkai, 2014).

Sakurajima is an icon of Kagoshima City and Kagoshima Prefecture, especially because of its commanding and active volcano. Its status is strengthened not only by the fact that it is visually conspicuous in Kagoshima Bay and directly opposite the urban waterfront of Kagoshima City (the capital of Kagoshima Prefecture and fourth largest city on Kyūshū), but also because it stands out as a natural attraction for visitors and locals alike. Sakurajima's volcano is the cynosure of all eyes and has had a major impact on the former island and region, and as such a number of volcano-related and other attractions have been developed to welcome visitors and contribute to the local economy.

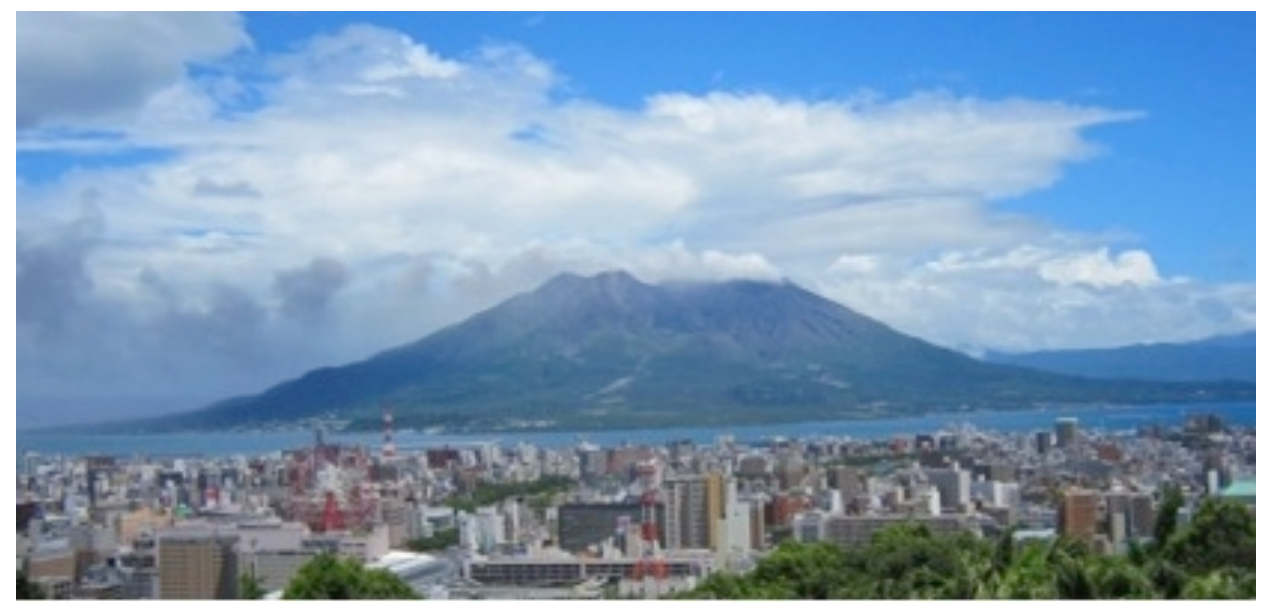

Figure 1 - Sakurajima viewed from Kagoshima City. (Photo: Sueo Kuwahara, 2010.)

This article is a study of the life of Sakurajima. The purpose of the article is to argue that while Sakurajima has been transformed from an island to a peninsula, it has still maintained a sense of islandness through various island-related tropes. Even though Sakurajima is now a protruding near circular landmass joined to the Ösumi Peninsula (Ōsumi-hantō), in this article it is discussed in terms of its island essence as determined by its name, shape, travel and tourism. The research methods used for gathering data for this article draw primarily from historical critical studies, especially in terms of collecting factual materials on Sakurajima, and from cultural studies in connection with interpreting notions of travel and islandness. The authors have visited and undertaken research on Sakurjima on many occasions, including talking to administrative and community leaders. The article is intended to offer Sakurajima as a case study for challenging ideas of islandness, and for offering discussion on the transformative nature of some islands and the ways they can be viewed more broadly.

Shima: The International Journal of Research into Island Cultures

Volume 10 Number 12015 
This paper draws from several main theoretical sources: toponymy and the broad interdisciplinary field of Island Studies. Toponymy offers a means of interpreting terms that no longer denote what they once did (eg, Taylor, 1865); and Island Studies provides theory in terms of travel to and from the island (for visitors and residents), both as a destination for tourists and also the mode of transition from one place to another (eg, Clifford, 1997; Hannerz, 1996; 1997). Indeed, the field of Island Studies has examples that can be compared to Sakurajima as a way of examining the sense of islandness in that this former island is able to maintain an island identity in several ways (eg, Baldacchino, 2007a, $2007 \mathrm{~b})$. In connection with studying Sakurajima in the present day, ideas can be drawn from Watson, who states that, "it probably makes best sense to use a definition of 'island' which recognises varying degrees of closeness to a prototype of the term instead of a set of essential criteria" (1998: 132). In other words, even though Sakurajima used to be an island, there are arguments that can be put forward, as in the discussion that follows, where such a landmass can still be explored not only historically as an island, but also in the present day as almost an island. It is here that the French term for peninsulas, 'presqu'iles' ('almost islands'), might be used to aptly describe Sakurajima.

Following this short introduction, the article divides into two main parts. The first of these locates Sakurajima in the broader Japanese context, moving from nation (Japan) to prefecture (Kagoshima Prefecture), and then to city (Kagoshima City) and island (Sakurajima). The analysis also provides a history of Sakurajima in terms of its geological existence and volcanic activity over many centuries. Following this section, a discussion is offered that focuses on Sakurajima's physical features in connection with its name and shape, and the means of travel to and from the former island.

\section{Location and History}

Sakurajima is located at $3135 \mathrm{~N}, 13040 \mathrm{E}$ (figs 1-4). It has one of many active volcanoes in the south of Japan that form a chain through the island of Kyūshū (i.e., Kirishima, which lies to the north of Sakurajima and is also in Kagoshima Prefecture; and Tsurumidake and Garandake in Ōita Prefecture) and the Nansei Islands to the southwest of Kyūshū, especially the northern islands (i.e., Satsuma-Iōjima and Suwanosejima) (there are many not so recently active volcanoes) (Kinoshita and Sakamoto, 2013). Sakurajima is physically (not administratively) joined to Tarumizu City on the Ōsumi Peninsula, and situated almost directly in front of the urban part of Kagoshima City on the Satsuma Peninsula (Satsuma-hantō) and towards the northern end of Kagoshima Bay. ${ }^{6}$ Kagoshima Bay forms a harbour about $80 \mathrm{~km}$ long and $20 \mathrm{~km}$ at its widest point, and the size and location of Sakurajima is such that is creates a much narrower sea passage at this part of the bay.

The population of Sakurajima before the 1914 eruption was 23,738 with 20 hamlets distributed around the island (Omori, 1914: 3). However, the population of Sakurajima is currently about 4700 . The former island has a circumference of about $52 \mathrm{~km}$, and much of the landmass is covered with steep mountains, barren land and lava. Sakurajima is administratively now a part of Kagoshima City (from now on referring to the main urban centre), and the former island divides into two main towns (chō), Higashi Sakurajima Town (Higashi Sakurajima-chō [East Sakurajima Town]) and Sakurajima Town (Sakurajima-chō), which comprise 18 smaller towns that are distributed around the low-lying coastal areas. The eastern part of Sakurajima has a much smaller population than the western side (Table

Shima: The International Journal of Research into Island Cultures

Volume 10 Number 12015 
1). While Higashi Sakurajima Town was incorporated into Kagoshima City in 1950, and has a branch office in Kagoshima City Hall, Sakurajima Town was incorporated into Kagoshima City in 2004 (also having a branch office of Kagsohima City Hall). Today, the two towns are also considered districts (chiku) within Kagoshima City. There are 11 towns under Sakurajima-chō, and 7 towns in Higashi Sakurajima-chō.

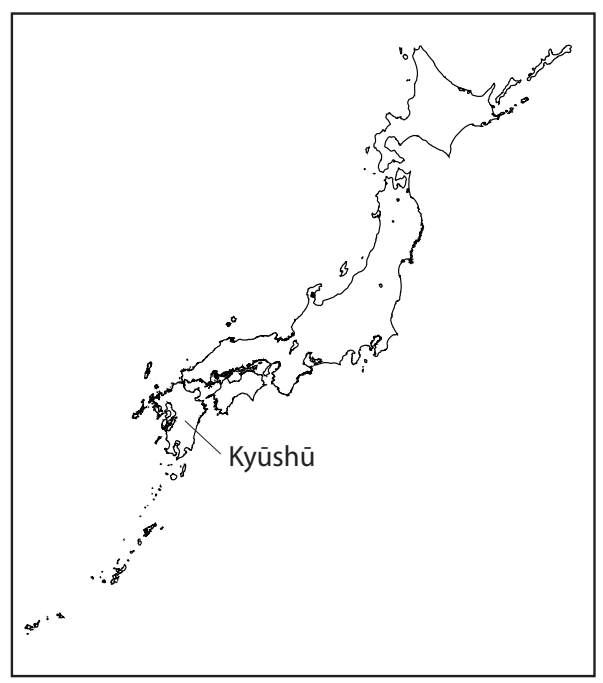

(a)

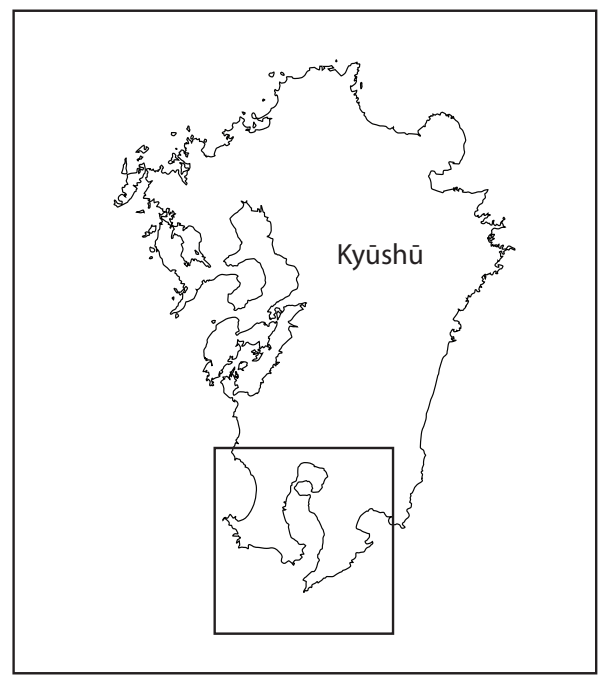

(b)

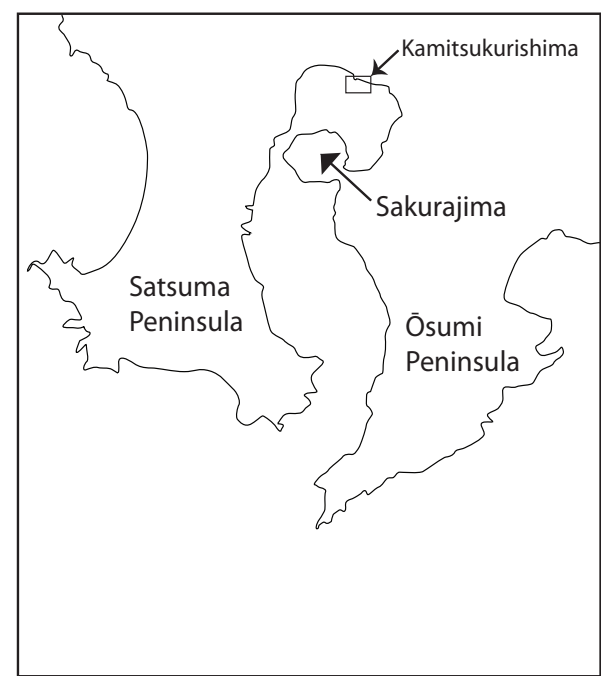

(c)

Figure 3 - (a) Japan; (b) Kyūshū; (c) Southern Kyūshū. (After http://english.freemap.jp (accessed 1 March 2014). Illustration by Henry Johnson, 2014.)

Shima: The International Journal of Research into Island Cultures Volume 10 Number 12015 


\begin{tabular}{|l|l|}
\hline Town & Population \\
\hline Higashi Sakurajima-chō & 1,201 \\
\hline Sakurajima-chō & 3,546 \\
\hline TOTAL & 4,747 \\
\hline
\end{tabular}

Table 1 - Population of Towns on Sakurajima (as of 1 February 2014) Source: Kagoshima Shiyakusho (2014c).

Geologically, Sakurajima is within the Aira caldera, along with the northern part of Kagoshima Bay, and was formed about 26,00o years ago from a stratovolcano (Geological Survey of Japan, 2014; Omori, 1914; Sagala, 2009; Sakurajima Taishō Funka, 10o-shūnen Jigyō Jikkō Iinkai, 2014; Yokoyama, 1997). The andesitic volcano has had several major eruptions over the centuries (Table 2). The summit of the volcano divides into three peaks: On-take (also called Kita-dake: northern peak; $1117 \mathrm{~m}$ ), Naka-dake (central peak; $1060 \mathrm{~m}$ ) and Minami-dake (southern peak; $1040 \mathrm{~m}$ ), the latter of which is currently active. In recent history, the most significant eruption of the volcano on Sakurajima occurred on 11 January 1914, after being dormant for about one century (Sagala, 2009: 54), when, over several days, a massive volcanic flow filled the Seto Straight (Seto Kaikyō) and joined the island to the Ōsumi Peninsula. The lava flow also joined several outlying islands to Sakurajima. ${ }^{2}$ Since 1955, the volcano has become more active, and continues to erupt to this day.

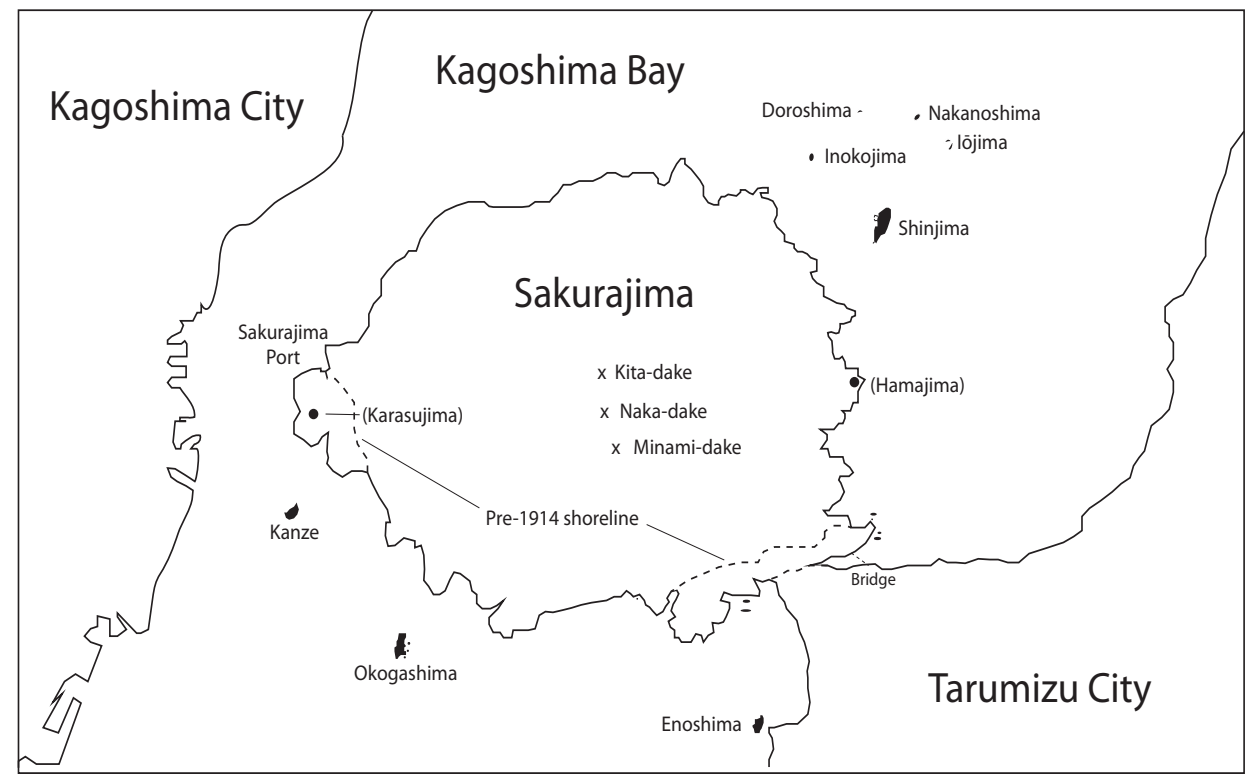

Figure 4 - Sakurajima and surrounding region. (After http://english.freemap.jp - accessed March 1st 2014, illustration by Henry Johnson, 2014.)

\footnotetext{
${ }^{2}$ For information on the 1ooth anniversary of the 1914 eruption see Sakurajima Taishō Funka 1ooshūnen Jigyō Jikkō Iinkai (2014).
} 


\begin{tabular}{|l|l|}
\hline Year & Details \\
\hline 764 & $\begin{array}{l}\text { Tenpyō-hōji eruption. Birth of three new islands to the north of Kagoshima Bay, } \\
\text { which are collectively known as Kamitsukurijima. }\end{array}$ \\
\hline 1471 & $\begin{array}{l}\text { Bunmei eruption. Birth of a new island in 1474, which was eventually joined to the } \\
\text { mainland to form the Moezaki Peninsula. }\end{array}$ \\
\hline 1779 & $\begin{array}{l}\text { An'ei eruption. Several new islands in the northeast were formed as a result of } \\
\text { submarine eruptions. The islands either sank soon after or were joined with each } \\
\text { other. Five main islands were formed: Inokojima, Nakanoshima, Iojima, Shinjima } \\
\text { and Doroshima. Collectively called An'ei Islands (after the era of Japanese history at } \\
\text { this time) and today only the first four remain (Kobayashi, 2oog). }\end{array}$ \\
\hline 1914 & $\begin{array}{l}\text { Taishō eruption. Lava flow connected the island to the Ōsumi Peninsula. Buried } \\
\text { Akamizu Town and Karasujima (Crow Island) to the west of Sakurajima, as well as } \\
\text { several villages on the slope. Fifty eight deaths and many injuries. }\end{array}$ \\
\hline 1946 & Shōwa eruption. Buried Kurokami Village and part of Arimura Village. \\
\hline $1955^{-}$ & Many eruptions from Minami-dake peak. \\
\hline
\end{tabular}

Table 2 - Main Volcanic Eruptions on Sakurajima ${ }^{3}$ (Source: Sakurajima Taishō Funka 10oshūnen Jigyō Jikkō linkai [2014]). (NB Numerous other eruptions have taken place (see Disaster Prevention Research Institute Kyoto University, 2012; Smithsonian Institution, 2014).

\section{Aspects of Islandness}

Sakurajima has many physical features that help it maintain an appearance similar to an island, and the locality might be perceived as an "island enclave" (Baldacchino, 2010) that is no longer surrounded by water. Just as, for example, Lesotho, Gibraltar or any landlocked or isolated community might be thought of as an 'island' by analogy, ${ }^{4}$ so too might Sakurajima be discerned as an island-both a former island and an island in essence. As a

\footnotetext{
${ }^{3}$ Several islands in Kagoshima Bay were formed as a result of submarine volcanic outbursts, including three small islands in the northern part of Kagoshima Bay to the far north of Sakurajima: Okikojima (Offshore Small Island), Bentenjima (Benten Island [named after a Japanese god]) and Hetakojima (Heta Small Island), which were a result of the $764 \mathrm{AD}$ eruptions (Omori 1914, 4). Immediately off the shores of Sakurajima are the An'ei Islands (An'ei-shotō), which are named after the Japanese An'ei era (1772-80) (Kagoshima Shiyakusho, 2014a; Kotō, 1916-17: 20-31, 48-53; Omori, 1914: 2-3; Omori, 1916a: 6872). To the south of Sakurajima are Okogashima (which uses the same kanji [Japanese ideograph] as Okikojima), Kanze (God's Shoal) and Enoshima (Inlet Island). Karasujima (Crow Island) was an island off the west coast of Sakurajima, but was engulfed by lava in 1914. Off the southeast coast of Sakurajima was Hamajima (Beach Island), which was also a new island formed by submarine activity during the An'ei era, although it was joined to Sakurajima during a 1946 lava flow. While Sakurajima itself has a significant population, of the various islands around Sakurajima, only Shinjima is populated (just one person lives there).

${ }^{4}$ Gibraltar is actually a member of the Island Games.
} 
way of contributing to discourse on locations that are similar to islands, this part of the article scrutinises themes that have surfaced during the research process that help reinforce an appreciation of Sakurajima as a former island and a location that is almost an island. That is, ideas pertaining to Sakurajima in terms of its name, shape, travel and tourism are given special consideration.

Name and Shape. For Sakurajima, and similar to some of the places mentioned above, the former island has a word as part of its name that still means 'island': the suffix jima/shima (island). As a place name, the word 'Sakurajima' could be changed as a way of indicatingthe location's new physical existence, just as villages become towns, and towns become cities (in Japanese, each has an appropriate suffix), although, for the reasons outlined later on, this is unlikely to happen for Sakurajima. One of these reasons might be that as a location its name is fixed as a place name and there is no wish to change it, regardless of the fact that 'Cherry Island' is no longer an island. Another reason might be that Sakurajima still maintains many characteristics that are island-like (as discussed below). Another reason is that there are many other locations called shima in Japan that refer not only to islands, but also to places that are not islands. For example, there are places such as Fukushima and Hiroshima on Japan's largest island of Honshū, both of which are names of cities and prefectures. Closer to Sakurajima, there are several other 'island' names used for places that are not islands. For instance, the very prefecture in which Sakurajima is located is called Kagoshima-ken (Fawn Island Prefecture); the name for the largest city in the prefecture is Kagoshima-shi; and, as mentioned earlier, a nearby city is called Kirishima-shi (Fog Island City).

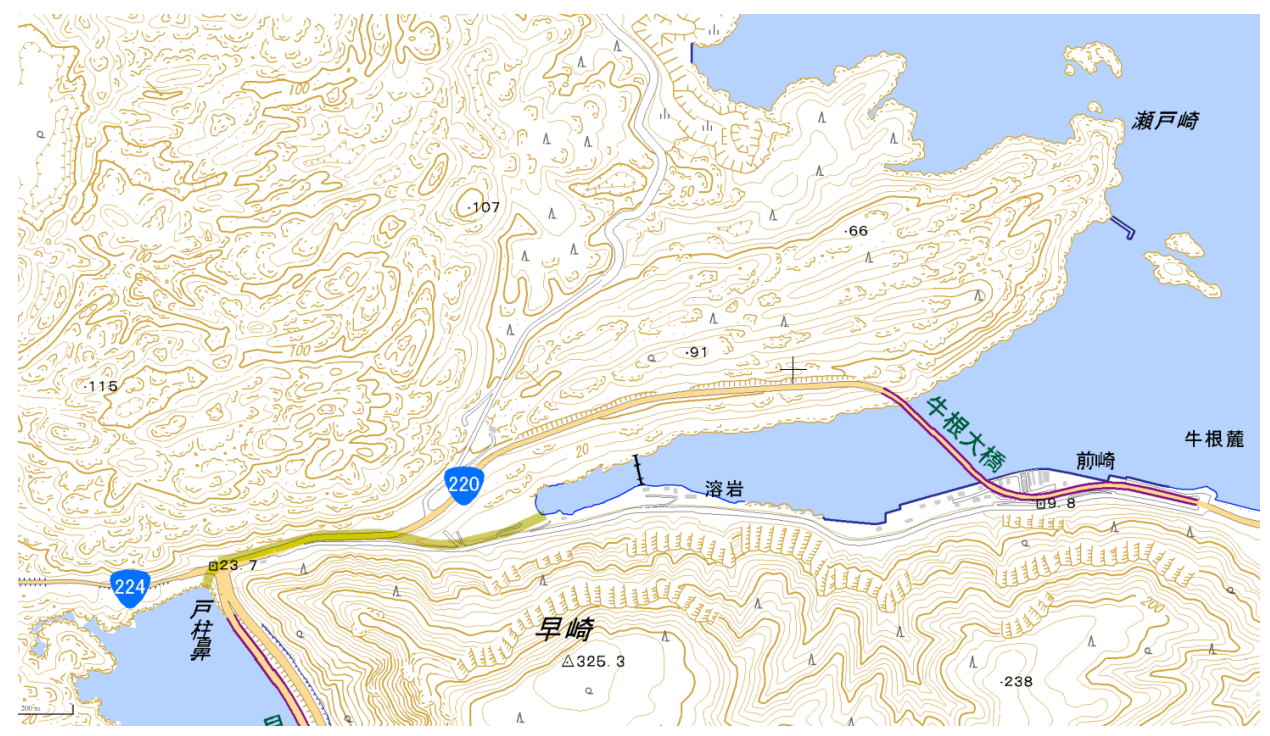

Figure 5. Map of lava link and bridge between Sakurajima and the Ōsumi Peninsula.

(Courtesy of the Geospatial Information Authority of Japan, http://www.gsi.go.jp - accessed 1 March 2014).

As well as denoting 'island', the word 'shima' has other meanings in Japanese, whether the sound or the kanji used to write the sound. For example, and especially in the Nansei 
Islands to the nation's southwest, the word shima can also mean community, and hence refer to an enclave that is viewed as being an island by analogy (cf. Gillan, 2012; Hayward and Kuwahara, 2008; Lebra and Maretzki, 1963; Peters, 2011; Suwa, 2007; Takara, 1993; 1987). Referring to the research of Takara, Suwa notes the following in connection with the notion of shima:

In Japanese... the idea of shima always contains a double image: shima as a geographical feature and shima as a community. In Okinawa... shima was a political unit equivalent to a village and the term still retains such connotations there. (2007: 7)

Suwa also shows the importance of the notion of shima as a village or community in the Nansei Islands, noting that, "neighbourhoods are imagined as if they are separate islands" (Suwa, 2007: 8). The term 'shima' can also refer to territory in another way, such as that of a gang or a prostitute. For example, a quote from the film Blue Spring (Aoi Haru; Toyoda, 2001) offers a relevant case in point: "Graffiti is spray-painted in the corridor to mark the school as 'Kujō's territory' (Kujō no shima)” (Barber, 2013: 126). Also, in the sixteenth century, fabric brought into Japan by Dutch and Portuguese traders was known as shimamono (island goods), but the meaning of shima in this instance was 'foreign land'. However, later in the Edo period (1600-1868) similar fabric was produced in Japan with a kanji meaning 'striped', which is also pronounced 'shima', after the pattern of the material, in place of the 'island' kanji (Takekoshi, [1930] 2004: 351). Such notions of islandness can be compared with Howell's (2005) work on Japanese geographies of identity, and in this context Sakurajima is both a former island and an island by analogy.

There are many locations the world over that are no longer islands, but often retain the word 'island' in their name. For example, Coney Island (US), Canvey Island (UK) and Thorney Island (UK) were each at one time islands, but have since been joined to a mainland. When the term 'island' is maintained in such place names, and there is no physical movement across water to a real island, there is, as Coates calls it, "onomastic divorce of names from the matrix of their source language" (2006a: 314; see also 2006b). That is, the word 'island' might continue to be used, but it no longer literally means an 'island' during discourse. With Sakurajima, when the notion of onomastic divorce is applied to this former island, in the sense that the name of the location still includes the suffix 'island', there is actually a level of preservation in the name's original meaning of 'Cherry Island' (at least the 'island' part of the name) in that the location maintains features that still allow visitors and residents alike to have an island-like experience when traveling to and from the former island. As outlined in more detail below, this might be termed 'onomastic resemblance' in that Sakurajima is known not to be an island, yet the location resembles an island in terms of its distinguishable features, location and modes of travel connected with it.

There are also islands that proclaim they are no longer islands by way of analogy. For instance, in 1906, Lord Northcliffe, the owner of the Daily Mail (an English newspaper), was angered by his editors' lack of reporting of Alberto Santos-Dumont's groundbreaking aeronautical flight and "cabled his own headline - England [sic] is no longer an island" (Paris, 1992: 66). The point here is that even though Northcliffe referred to England as an island, and perhaps meant the island of Great Britain, he was implying that aeronautics was a conduit from island to mainland and beyond. In other words, flight offered a means of transport without having to travel on water. Analogies can be made to bridges that link

Shima: The International Journal of Research into Island Cultures

Volume 10 Number 12015 
islands to mainlands, with such links providing a way of opening up a means of travel to and from an island (Baldacchino, 2007a; b). Other 'island' analogies might also be made, such as Berlin in the days of former East Germany (see further Collins and Wellman, 2010; Island Vulnerability, 2014). There are also places such as Lisle in France, which, as its very name suggests, was "once an island" (Taylor, 1865: 355). Indeed, Taylor (1865) discusses many places that have undergone physical changes, but with their names attesting to their original meaning. For example:

The Anglo-Saxon word ea or ey, an island, enters into the composition of the names of many places by the river-side which are now joined to the mainland by rich pastures. Bermondsey, Putney, Chertsey, Moulsey, Iffley, Osney, Whitney, and Eton or Eaton, were all islands in the lagoon. (Taylor, 1865:348)

Regarding Sakurajima's shape, it is important to note that it is almost circular, and it protrudes from the Ōsumi Peninsula as though it were almost an island (a presqu'ile), especially when viewed from the populous Kagoshima City, and with just a very narrow point of connection to the mainland. From this vantage point, Sakurajima gives the impression that it is surrounded by water. As Baldacchino (2005: 247) notes, islands are frequently drawn from an aerial perspective; with a circular shape, but, of course, as Williams points out, they are much more complex: "there is a common conception (or rather misconception) with the pictorial representation of islands erring towards a perfect, totalizing circumscription of space" (2012: 215). Adding to this image of Sakurajima is the fact that even the point where Sakurajima joins the Ôsumi Peninsula is extremely narrow and not easily visible from a distance. Thus, Sakurajima is a protuberance emanating from the Ôsumi Peninsula, and, as commented on by one writer, "Sakurajima still feels every bit an island and looks like one from [the main urban part of] Kagoshima” (Brown, 1994: 168).

A major part of Sakurajima that adds to the island shape trope is its towering volcano. Forming a dominant part of Sakurajima, and located almost centrally with several main peaks, the volcano is Sakurajima's main physical feature. From any location on the inhabitable parts of Sakurajima (i.e., around the coastline) the volcano is present, as it is from further afield. It rises high above the low-lying land around Sakurajima's coastline, and since 1955 has regularly erupted with bursts of smoke and ash. The imposing volcano is a physical trait that also contributes to the former island maintaining a sense of islandness, at least in terms of its visual appearance.

Travel and Tourism. Sakurajima maintains a sense of being an island not only in its name, but also in the means of transport to the former island used by many visitors and residents-by sea (by vehicle and passenger ferry) or by land (across a bridge). Such routes offer a sense of transition from one location to another, both reflecting an historical part of Sakurajima's historical existence as an island, and also its contemporary identity in that the sea passage is the same as it was when Sakurajima was actually an island, and the journey across the bridge adds to the perception of passing from mainland to 'island' or vice versa.

As mentioned earlier, Sakurajima joins the Ôsumi Peninsula at Tarumizu City (the join is about 8oom long), which has a population of 16,699 (Tarumizu Shiyakusho, 2014). In contrast, Kagoshima City's population is much larger at 607,687 (Kagoshima Shiyakusho, 2014c). As noted, road access is possible from the Ösumi Peninsula, but travelers and commuters are more likely to take the passenger and car ferry service that runs between Kagoshima City and Sakurajima because of the size of the population of Kagoshima City,

Shima: The International Journal of Research into Island Cultures

Volume 10 Number 12015 
the ease of access, and because of the main trunk road access to and from Kagoshima City to other parts of Kyūshū. The number of passengers and vehicles on the ferry service is considerable and has remained around 3.6 million passengers and 1.5 million vehicles per annum for the past ten years (Kagoshima Shiyakusho, 2014b).

The main public access point on the former island for traveling by sea is Sakurajima Port (Sakurajima-kō). Travel to many islands is often by sea, and the short journey from Kagoshima City to Sakurajima offers a sense of movement from mainland to island. During peak times of the day (i.e., 8.00-10.00 am and 3.00-6.00 pm), the ferry service currently operates with boats departing both ports every 10 minutes, and the journey lasting 15 minutes. A ferry service operates 24 hours/day, and each ferry carries vehicles and passengers. There are also sightseeing cruises available offering a trip very close to Sakurajima, which run several times a day for one or two hours. As an important mode of transport to Sakurajima from the highly populous Kagoshima City, the ferry crossing helps Sakurajima maintain an island characteristic. That is, the almost ritualistic modes of behaviour that are part of the process of taking a ferry to Sakurajima are the same as a similar journey when traveling to an island. While many sea journeys are not to islands, Sakurajima's contributing features of once being an island, having an island suffix and an almost circular shape, add to this sense of islandness. The sea journey offers a sense of liminality, moving from one realm to another with the process of taking a ferry acting as a conduit between two places (cf. Turner, 1977). Moreover, as Baldacchino comments, "the surrounding sea, the very isolation of an island, lies at the heart of its 'lure' or 'fascination' to visitors (eg, Baum 1997; Lockhart 1997), while also affording some, even if tokenistic, sense of protection to those who live there" (Baldacchino, 2007b: 327 ). Indeed, the sea is an important trope in everyday life on Sakurajima, so much so that it is emphasised (along with mountains) in some song texts that are important to some residents, such as in the first verse of the school anthem of Higashi Sakurajima Chūgakkō (Higashi Sakurajima Junior Highschool):

\begin{tabular}{|l|l|}
\hline Yama ni nozomeba, yama no koe & $\begin{array}{l}\text { If we see the mountain, we can hear the voice of the } \\
\text { mountain }\end{array}$ \\
\hline Umi ni nozomeba, umi no koe & If we see the sea, we can hear the voice of sea \\
\hline Yama to umi to ga, yobi au naka ni & The flower of friendship blooms \\
\hline Yūai no hana, saki kaoru & While the mountain and sea call out to each other \\
\hline $\begin{array}{l}\text { Warera no Higashisakurajima } \\
\text { chūgakkō }\end{array}$ & Our East Sakurajima Junior High School \\
\hline
\end{tabular}

Source: Higashi Sakurajima Chūgakkō (2014).

This song celebrates the location of Higashi Sakurajima Junior Highschool, which was established in 1947, in a context where the sea, mountain and natural environment are important tropes that help create identity for the school's students. As such, the sea is reinforced as part of Sakurajima, at least in that it is almost surrounded by it.

Sakurajima also has physical links between its landmass and the Ōsumi Peninsula. There are two: (1) a join that was made as a result of the 1914 eruption; and (2) a bridge that passes over a narrow sea passage (the bridge is called Ushine Ōhashi [Ushine Large Bridge]) (figs 5-6). With regard to such physical connections, Watson has commented on islands in terms of what happens to their islandness when bridges are made between them and their respective mainlands, which might be compared to Sakurajima's lava and bridge links: 
Building a bridge to an island removes the discontinuity that is characteristic of islands in the first place. It means that an island, viewed from the mainland, no longer appears mysterious and inaccessible. Travelers no longer need to change transport modes. You can even walk from the island to the mainland without getting your feet wet. The rituals of passage to an island - waiting for the ferry, checking the weather, drinking coffee in the terminal cafeteria, walking up the ramp into the ship. pitching and tossing in the waves, tying up at the pier with thick rope - are reduced to an unremarkable car journey with perhaps a stop at a tollbooth. (Watson, 1998: 136; cf. Baldacchino, 2007a)

In this context, the former island of Sakurajima is able to maintain a sense of islandness by its ferry and bridge links to and from different ends of its landmass.

There are actually three roads linking Sakurajima to the main part of the Ōsumi Peninsula: (1) from the eastern point of the join between Sakurajima and the mainland; (2) over a bridge just to the east of the join; and (3) to the west of the join. Immediately after the 1914 lava flow there were no roads at this location, so travel to and from Sakurajima was exactly the same as when it was an island. The bridge is the largest of these roads and actually offers a further sense of islandness in terms of travel to and from Sakurajima. Many islands now have bridges linking them to mainlands, and while such connections offer a means of increasing access to or from an island, they also help challenge the definition of 'island' by extending land routes.

The bridge to Sakurajima, which is $381 \mathrm{~m}$ long, opened to traffic in 2008. It offers a slightly different perspective to bridging islands. Rather than creating the first link between mainland to island, in the case of Sakurajima, the bridge was built a long time after the lava flow had already connected these two landmasses. In this situation, the bridging of the former island shouldn't be regarded as only an additional transport route, but, rather, also as a link that contributes to maintaining Sakurajima as a type of island. For the traveler to or from Sakurajima, the addition of a bridge offers a sense of passing over water rather than land (as in the case of the road access across the lava flow), and rather than offering a sense of loosing a part of an island, for Sakurajima the bridge actually adds to the former island's continuing sense of islandness. Moreover, "a bridge thus symbolises either the connection between what is separated; and the separation between what is connected (van Houtum and Strüver 2002, 145); but would be next to meaningless to two locations, which are merely apart" (Baldacchino, 2007b: 324).

Both the ferry service and the road bridge offer competing modes of transport to and from Sakurajima. The former is just a short distance from Kagoshima City, but is reliant on a regular ferry service, while the latter is a long route around Kagoshima Bay to reach Kagoshima City. As noted above, each helps bring a sense of islandness in terms of highlighting the notion of traveling over water as part of an island-like journey. However, each impacts in different ways on the sense of local community by increasing the mobility of residents and visitors alike. Land transport offers a convenient means for people to move freely at any time, and while the road bridge provides such access, the ferry service must operate frequently in order to avoid long waiting times. For the local community, the ferry service offers a way of regulating access to and from Sakurajima, but as access is increased, either by ferry or road, greater influences from the outside contribute to weakening community sensibilities (Maehata, 2011). Because many ferry users are commuters from Sakurajima to Kagoshima City (Kagoshima Shiyakusho, 2014b), these travelers would help

Shima: The International Journal of Research into Island Cultures

Volume 10 Number 12015 
consolidate their local identity by sharing waiting times for the ferry and interacting over the short journey. In this setting, the ferry service helps create a communal context for locals, as another interpretation of islandness, whereas traveling by car over the bridge is more individual and a much longer journey. Also, in terms of cost, the ferry service is especially expensive if taking a vehicle, so most commuters are foot passengers or take a bicycle.

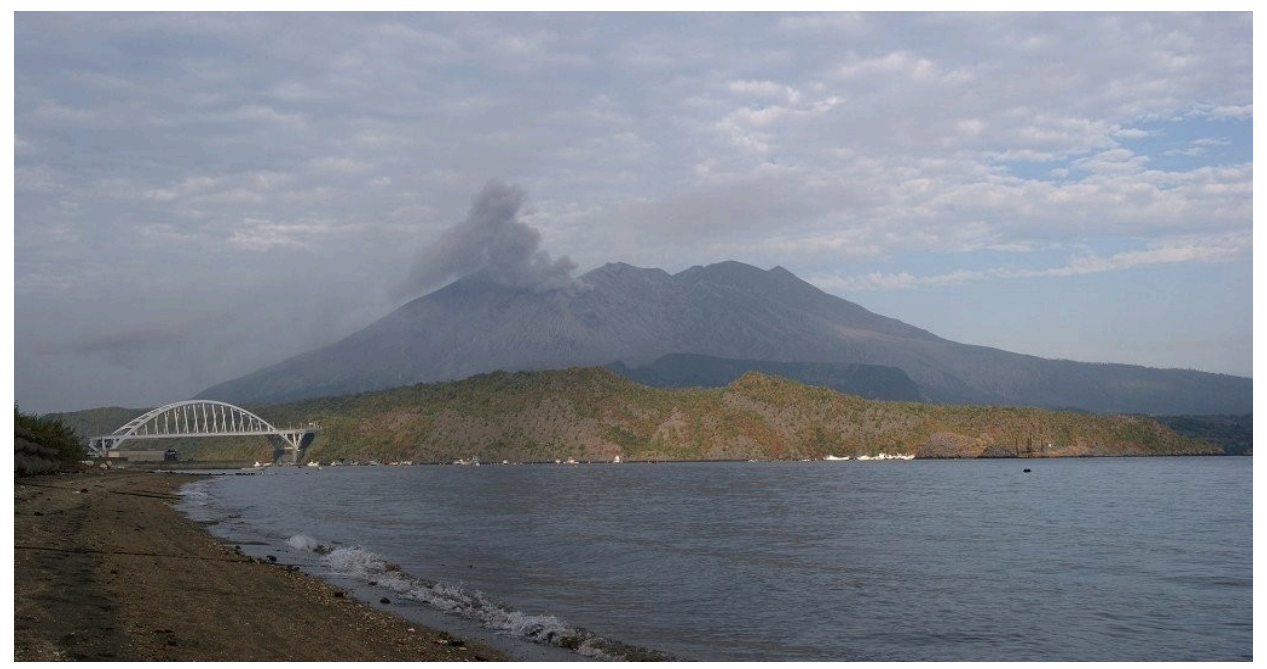

Figure 6. Ushine Ōhashi (bridge) between Sakurajima and the Ōsumi Peninsula. (Courtesy of PhotoMiyazaki(MORIMORI),

http://kagoshima.pmiyazaki.com/sakurajima/o2_ushine_br.htm - accessed 1 March 2014).

Nevertheless, according to one community leader interviewed in 2014, the perception of Sakurajima as an island or peninsula may differ according to age. The explanation offered noted that younger people prefer to use cars to go shopping to the nearby cities of Kokubu, Tarumizu and Kanoya because the cost of the car ferry to go to Kagoshima City is too expensive for them. Therefore, these younger people may perceive Sakurajima as a peninsula (or an island joined to the mainland by a bridge) and simply use the road bridge as part of their everyday activities. Older generations, however, tend to prefer to take the ferry to Kagoshima City, thus maintaining a sea journey between Sakurajima and the main city of which it is a part. However, during interviews with three administrative and community leaders (also in 2014), the consensus amongst this particular group of over sixty year olds was that Sakurajima did not maintain an island essence. This was due to Sakurajima now being a part of Kagoshima City and that this connection brought with it much convenience in travel, either by ferry or road bridge to main urban centres, and Sakurajima was by extension a part of Kagoshima City as an urban centre. While they noted that a ferry was still needed to travel to the main part of Kagoshima City, they felt they were not isolated in the same way that some people are on remote islands. The frequency and speed of the ferry was noted as one of the main reasons that they didn't perceive Sakurajima as an island, particularly because there wasn't really any time spent waiting for the ferry and the journey took just fifteen minutes. For this latter group of residents of Sakurajima, therefore, the notion of islandness has more to do with physical 
remoteness than the actual crossing of a narrow channel of water from one landmass to another.

As well as Sakurajima's road access points, it has a main road that runs around its circumference, which connects the various settlements that house its relatively small population. There are some roads that lead inland, but only within a safe distance to the volcano, and only a short distance up Sakurajima's precipitous slopes. This circular route around the low-lying and easily accessible part of the landmass, along with the mountainous interior, adds to the idea that one is navigating a route around an island, and comparisons could be made with many other actual islands where the coastal route is the main road.

There are many features on Sakurajima that contribute to it being an attraction for visitors (cf. Baum, 1997; Lockhart, 1997). The former island might be thought of as a "novelty site" (Baldacchino, 2010: 14) for various reasons outlined below. While similar sites might be found in many other places, their existence on Sakurajima contributes to the identity of the place, not only as an attraction for visitors, but also because they consolidate the former island as a location to go to and hence strengthen the various tropes that contribute to its islandness. There are many such visitor attractions in and around Sakurajima's ferry terminal, but also others more widely around the former island. The following list of twelve main attractions on Sakurajima is offered by Sakurajima Bijitā Sentā (2014):

- $\quad$ Lava Nagisa Beach Park and Public Foot-Spa (Yōgan Nagisa Kōen Ashiyu)

- Nagisa Lava Trail (Yōgan Nagisa Yūhodō)

- Sakurajima Fishing Park (Sakurajima Umitsurikōen)

- National Lodgings Rainbow Sakurajima (Sakurajima Maguma Hot Spring) (Kokumin Shukusha Reinbō Sakurajima - Maguma Onsen)

- Rest Spot 'Sakurajima' Hinoshima Megumikan (Michi no eki Sakurajima Hinoshimame Gumikan)

- Sakurajima Dinosaur Park (Sakurajima Shizen Kyōryū Kōen)

- Karasujima Observatory (Karasujima Tenbōjo)

- Yunohira Observatory (Yunohira Tenbōsho)

- Sakurajima International Volcanic Sabo Center (Kokusai Kazan Sabō Sentā)

- Furusato Hot Spring Area (Furusato Onsenkyō)

- Arimura Lava Observatory (Arimura Yōgan Tenbōjo)

- Kurokami Buried Shrine Gate (Kurokami Maibotsu Torii)

Also, there is the Sakurajima Island View Bus, which takes visitors from Sakurajima Port to Yunohira Observatory on a one-hour return journey with several stops at tourism sites along the way. An interested aspect of this feature of local tourism includes not only the bus and the touristic sites it takes passengers to, but the very name of the bus itself, which maintains the term 'island' in its name, a feature that is labelled clearly on the side of the bus in katakana script: 'Sakurajima Airando Byū' ('Sakurajima Island View'). It is with such references to Sakurajima as an island that the island trope is reinforced for locals and tourists alike.

The significance of Sakurajima as a distinct location stands out not only in terms of its dramatic physical features as a volcano in Kagoshima Bay and in close proximity to Kagoshima City (Cooper, 2014), but also with regard to some of its natural and cultural

Shima: The International Journal of Research into Island Cultures

Volume 10 Number 12015 
traits. As well as the sites and activities outlined above, Sakurajima is well known for its large-size white radish (daikon) and small variety of orange (komikan). Also, Sakurajima has been the location of large-scale cultural events, including the nine-hour, all-night rock concert in 2004 involving 75,000 music fans that was made into a musical documentary by film director Kitamura Ryūhei (2004). A large guitar monument is now located on the site of the concert at Akamizu View Park and is a prominent feature for tourists to visit.

One of the main visitor attractions on Sakurajima is the volcano that towers above the former island (Erfurt-Cooper, 2010; Sagala, 2009: 55). "Despite the ongoing activity of Mt Sakurajima volcano tourism is booming, starting on the mainland with hotels offering rooms with volcano views across Kagoshima Bay" (Erfurt-Cooper, 2010: 149). There is a special viewing platform at the Arimura Lava Observatory (Arimura Yōgan Tenbōjo), and there is a Sakurajima Volcano Research Center (Kazan Katsudō Kenkyū Sentā). There are also related sites such as the half buried Shintō shrine gate (torii), hot springs (onsen), and foot spas (ashiyu). While places with such attractions do not have to be islands, the fact that Sakurajima is a former island, and its volcano is both geographically and visually a centerpiece for the location, adds to the identity of Sakurajima and helps strengthen its important place in this part of Japan. Such sites include a:

10o-meter-long foot spa, a statue related to rock singer Nagabuchi Tsuyoshi, observation spots commanding a beautiful view, and abundant hot springs. These places are always crowded with visitors from Kagoshima and beyond. (Sakurajima Taishō Funka 1oo-shūnen Jigyō Jikkō Iinkai, 2014)

\section{Conclusion}

Sakurajima is a unique context as a case study of a location that is almost an island. Sakurajima was formed as an island around 26,00o years ago; it has been transformed in shape and size on many occasions as a result of numerous volcanic eruptions; and it was joined to the Ōsumi Peninsula in 1914 and lost its island physicality. Sakurajima maintains an island name. While the suffix 'jima' in its name allows the locality to be perceived as an island, at least to those who don't know it is no longer an island, the nomenclature also helps Sakurajima maintain an island-like identity. Other ways Sakurajima maintains an island identity are through its shape, sea travel, bridge and tourism. Concerning the former island's bridges (i.e., the lava join and the road bridge), the sea stands out as an important element that contributes to Sakurajima's islandness. Travel to and from Sakurajima mostly takes one of these routes, and the former island's almost circular shape and perimeter road allows the locality to be perceived as almost an island. Moreover, Sakurajima might also be understood as a 'shima' in terms of its territory as an island enclave: a distinct geographical place with an island history and continued island character.

In conclusion, relating back to the JR Kyūshū 'island' advertising campaign for Kagoshima as noted at the start of this paper, Sakurajima may no longer be an island, but it maintains island-like tropes that enhance its islandness. Once an island, Sakurajima is now a presqu'ile ('almost an island'); a part of the Ōsumi Peninsula (hantō: half island); and a part of the much bigger island of Kyūshū. Sakurajima has a distinct historical island past, and its post-1914 uniqueness in this part of Japan is continued by an alluring island essence reinforced through toponymy, shape, travel and tourism.

Shima: The International Journal of Research into Island Cultures

Volume 10 Number 12015 
Acknowledgement

The research for this article would not have been possible without the generous support of Kagoshima University Research Center for the Pacific Islands, and the University of Otago. Several community and administrative leaders were interviewed as part of the data gathering process for this paper and their names have been kept anonymous.

\section{BIBLIOGRAPHY:}

Baldacchino, G (2005) 'Islands: Objects of Representation', Geografiska Annaler. Serries B, Human Geography v87 n4: 247-251

(ed) (2007a) Bridging Islands: The Impact of Fixed Links, Charlottetown: Acorn Press

(2007b) 'Fixed Links and the Engagement of Islandness: Reviewing the Impact of the Confederation Bridge', The Canadian Geographer v51 n3: 323-336

(2010) Island Enclaves: Offshoring Strategies, Creative Governance, and Subnational Island Jurisdictions, Montreal: McGill-Queen's University Press

Barber, C (2013) 'Contingent Subjectivity and Masculinity in Japanese Film for Young People', in Stephens, J (ed) Subjectivity in Asian Children's Literature and Film: Global Theories and Implications, Abingdon: Routledge: 115-134

Baum, T (1997) 'The Fascination of Islands: A Tourist Perspective', in Lockhart, D and Drakakis-Smith, D (eds) Island Tourism: Trends and Prospects, London: Printer: 21-35

Brown, J (1994) The Sudden Disappearance of Japan: Journeys Through a Hidden Land, Santa Barbara: Capra Press

Chimei Yurai Jiten (2014) Kagoshima-ken: http://chimei-allguide.com/46/ooo.html accessed November 6th 2014

Clifford, J (1997) Routes: Travel and Translation in the Late Twentieth Century, Cambridge: Harvard University Press

Coates, R (2006a) 'Names', in Hogg, R and Denison, D (eds) A History of the English Language, Cambridge: Cambridge University Press: 312-351

(2006b) 'Singular Definite Expressions with a Unique Denotatum and the Limits of Properhood', Linguistics v38 n6: 1161-1174

Collins, J and Wellman, B (2010) 'Small Town in the Internet Society: Chapleau is no Longer an Island', American Behavioral Scientist v2o n1o: 1-23

Cooper, M (2014) 'Volcanic National Parks in Japan', in Erfurt-Cooper, P (ed) Volcanic Tourist Destinations, New York: Springer: 231-246

Disaster Prevention Research Institute Kyoto University (2012) Sakurajima Volcano: http://www.svo.dpri.kyoto-u.ac.jp/sakurajima_e.html - accessed January 13th 2014

Shima: The International Journal of Research into Island Cultures

Volume 10 Number 12015 
Erfurt-Cooper, P (2010) 'Volcano and Geothermal Tourism in Kyushu, Japan', in ErfurtCooper, P and Cooper, M (eds) Volcano and Geothermal Tourism: Sustainable GeoResources for Leisure and Recreation, London: Earthscan: 142-154

Geological Survey of Japan (2014) Sakurajima Volcano: http://gbank.gsj.jp/volcano$\mathrm{AV} /$ volcmap/o1/text/eng/expo1-3e.html - accessed January 13th 2014

Gillan, M (2012) Songs from the Edge of Japan: Music-making in Yaeyama and Okinawa, Farnham: Ashgate Publishing

Hannerz, U (1996) Transnational Connections, London: Routledge

Hayward, P and Kuwahara, S (2008) 'Retaining Shima in Shima Uta: Music as Mnemonic Expression of Heritage in Contemporary Kakeroma', in Novaczek, I (ed) Refereed Papers From the 3rd International Small Island Cultures Conference, Sydney, Small Island Cultures Research Initiative: 64-68, archived online at: http://sicri-network.org/archives/ISIC 3 accessed September 8th 2012

Higashi Sakurajima Chūgakkō (2014) Kōka: http://keinet.com/hisakuc - accessed November 6th 2014

Howell, D (2005) Geographies of Identity in Nineteenth-Century Japan, Berkeley: University of California Press

Island Vulnerability (2014) 'Background':

http://www.islandvulnerability.org/background.html - accessed January 19th 2014

Kagoshima Kenchō (2014) Koshikijima:

http://www.pref.kagoshima.jp/ab23/pr/gaiyou/rekishi/bunka/yurai.html\#9 - accessed November 6th 2014

Kagoshima Shiyakusho (2014a) Kinkōwan Miryoku Saihakken Kurūzu: http://www.city.kagoshima.lg.jp/sakurajima-ferry/_45502.html - accessed January 16th 2014

(2014b) Sakurajima Ferī no Yusō Jōkyō (Heisei 19-23-nendo):

http://www.city.kagoshima.lg.jp/_1010/shimin/7siseijouhou/7-15tokei/7-15-3/7-15-3-1/7-15-31-2/o004023.html - accessed February 26th 2014

(2014c) Tōkei Jōhō: http://www.city.kagoshima.lg.jp/_1010/shimin/7siseijouhou/715tokei.html - accessed March 4th 2014

Kinoshita, K and Sakamoto, M (2013) 'Volcanic Island Chain South of Kyushu, Japan', in Kawai, K, Terada, R and Kuwahara, S (eds) The Islands of Kagoshima: Culture, Society, Industry and Nature, Kagoshima: Kagoshima University Research Center for the Pacific Islands: 128-135 
Kobayashi, T (2009) 'Origin of New Islets (An-ei islets) Formed During the An-ei Eruption (1779-1782) of Sakurajima Volcano, Southern Kyushu, Japan', Bulletin of the Volcanological Society of Japan v54: 1-13

Kotō, B (1916-17) 'The Great Eruption of Sakura-jima in 1914', The Journal of the College of Science, Imperial University of Tokyo v38: 1-237

Lebra, W and Maretzki, T (1963) 'The Community Cooperative in Northern Okinawa', Economic Development and Cultural Change v11 n3: 225-238

Lockhart, D (1997) 'Islands and Tourism: An Overview', in Lockhart, D and Drakakis-Smith, D (eds) Island Tourism: Trends and Prospects, London: Printer: xiii-xv

Maehata, A (2011) 'Okinawa Kouritō ni okeru kakyō-ka ni yoru shakai hen'yō', Jinmon Chiri v63 n4: 344-359

Omori [Ōmori], F (1914) 'The Sakura-jima Eruptions and Earthquakes, I', Bulletin of the Imperial Earthquake Investigation Committee v8 n1: 1-34

(1916a) 'The Sakura-jima Eruptions and Earthquakes, II', Bulletin of the Imperial Earthquake Investigation Committee v8 n2: 35-179

(1916b) 'The Sakura-jima Eruptions and Earthquakes, III', Bulletin of the Imperial Earthquake Investigation Committee v8 n3: 181-321

Paris, M (1992) Winged Warfare: The Literature and Theory of Aerial Warfare in Britain, 1859-1917, Manchester: Manchester University Press

Peters, I (2011) 'A Sea of Stories: Islands as Shima in Rattawut Lapcharoensap's Sightseeing', Ariel: A Review of International English Literature v41 nı: 143-161

Sagala, S (2009) 'Systems Analysis of Social Resilience Against Volcanic Risks', (unpublished) Doctor of Engineering dissertation, Kyoto University

Sakurajima Taishō Funka 10o-shūnen Jigyō Jikkō Iinkai (2014) Sakurajima Taishō Funka 100-shūnen: sakurajimaıo.org - accessed February 26th 2014

Sakurajima Bijitā Sentā (2014) Shūhen Gaido: http://www.sakurajima.gr.jp/svc/guide accessed February 23rd 2014

Sakurajima Japan (2014) http://sakura-jima.weebly.com/information-and-pictures.html accessed November 6th 2014

Shoku nihonki ([794] 2014) Asahishinbun Hon: http://www.j-texts.com/jodai/shokuall.html - accessed March 9th 2014

Smithsonian Institution (2014) Global Volcanism Program: http://www.volcano.si.edu/volcano.cfm?vn=28208o - accessed February 24 th 2014 
Suwa, J (2007) 'The Space of Shima', Shima: The International Journal of Research into Island Cultures vı nı: 6-14

Takara, K (1987) Ryūkyū Ōkoku no kōzō Tōkyō: Yoshikawa Kōbunkan (1993) Ryūkyū Ōkoku Tōkyō: Iwanami Shoten

Takekoshi, Y ([1930] 2004) The Economic Aspects of the History of the Civilization of Japan Volume 2, London: Taylor \& Francis

Tarumizu Shiyakusho (2014) Tarumizu-shi: http://www.city.tarumizu.lg.jp - accessed March 4th 2014

Taylor, I (1865) Words and Places: or, Etymological Illustrations of History, Ethnology, and Geography (2nd edition), London: Macmillan

Toyoda, T (director) (2001) Aoi Haru, Tokyo: Aoi Haru Seisaku Iinkai

Turner, V (1977) 'Variations on a Theme of Liminality', in Moore, S and Myerhoff, B (eds) Secular ritual, Assen: Van Gorcum: 36-52

Watson, I (1998) 'The Challenge of Maintaining Parity for Offshore Islands', Middle States Geographer v31: 132-137

Williams, S (2012) 'Virtually Impossible: Deleuze and Derrida on the Political Problem of Islands (and Island Studies)', Island Studies Journal v7 n2: 215-234

Yokoyama, I (1997) 'An Interpretation of the 1914 Eruption of Sakurajima Volcano', Proceedings of the Japan Academy v73: 53-58 